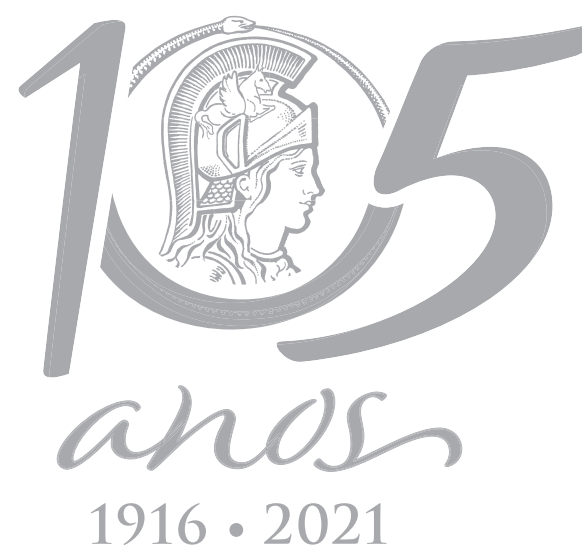

\title{
ECOSYSTEMS
}

\section{Can our current knowledge and practice allow ecological restoration in the Cerrado?}

\author{
NATÁLIA F. MEDEIROS, GERALDO WILSON FERNANDES, ANANZA MARA RABELLO, \\ THAIISE O. BAHIA \& RICARDO R.C. SOLAR
}

\begin{abstract}
Ecological knowledge plays a significant role in ensuring efficient ecological restoration. We conducted a systematic review to assess if sufficient ecological knowledge has been accumulated to aid restoration practices for the Cerrado, a Brazilian biome dominated by savanna ecosystems and threatened by anthropogenic disturbances. Most Cerrado restoration studies were performed by few research groups and focused primarily on two vegetation types: cerrado sensu stricto (typical savanna) and riparian forest. We also found that defining reference ecosystems and selecting plant species for restoration programs is neglected, mostly disregarding their original occurrence and proportion of plant growth forms. Furthermore, studies lacked standardized and systematic evaluation of restoration outcomes. Hence, we argue that current ecological knowledge is insufficient to guarantee the success of large-scale ecological restoration of the Cerrado. We strengthen the need to explicitly define the reference ecosystem for each Cerrado ecosystem and use its structure and composition as guidance for ecological restoration research, which should be based on a scientific approach. We encourage investigations into ecological dynamics and natural regeneration of the different vegetation types of the Cerrado and highlight the importance of integrating such knowledge with environmental laws, societal engagement and cost-effective techniques to advance Cerrado ecological restoration.
\end{abstract}

Key words: afforestation, Brazilian savanna, Cerrado hotspot, ecological restoration, savanna restoration.

\section{INTRODUCTION}

The current expansion of human activities has led to unprecedented conversion, degradation and fragmentation of native ecosystems (Fahrig 2003, Newbold et al. 2015) with dreadful consequences for biodiversity and ecosystem functions worldwide (Barlow et al. 2016, Fernandes et al. 2018). As a response, conservation initiatives aiming to maintain native vegetation have been increasingly fostered throughout the globe, but it is disputable whether they will be enough and in time (Rands et al. 2010). The ramping rates of degradation and fragmentation require multiple actions to fully conserve biodiversity and ecosystems, including ecological restoration of degraded ecosystems (Suding et al. 2015). Nevertheless, the practice and enhancement of ecological restoration is hindered by several issues such as the need to advance and integrate political incentives, societal engagement, costeffective techniques and ecological knowledge (McDonald et al. 2016, Montoya et al. 2012, Richardson \& Lefroy 2016). The establishment of a consistent ecological foundation is key to guiding restoration practices into a sciencebased approach that ensures successful results. 
Consistent ecological knowledge at different temporal and spatial scales is important for efficient use of natural resources and financial support to ensure well-planned restoration (Audino et al. 2017, Bustamante et al. 2019). Moreover, restoration actions must be guided towards a previously established reference ecosystem, which is usually represented by a non-degraded version of the target ecosystem. Appropriate restoration actions should consider the structure and composition of the reference ecosystem, as well as the degradation level of the ecosystem to be restored (McDonald et al.
2016). The degree to which ecosystems change due to disturbances is related to their capacities of resistance (ability to tolerate or adapt during the disturbance) and resilience (ability to recover after softening the disturbance) (Nimmo et al. 2015). These capacities can be expected to vary among ecosystems with different characteristics and evolutionary histories. In this context, each type of ecosystem requires specific restoration approaches and interventions (see Table I). Therefore, understanding the capacities of resistance and resilience of the target ecosystem can help guide restoration in a more sustainable

Table I. Ecological information on intact savanna and forest ecossystems and restoration interventions recommended to restore degraded areas of each ecossystem.

\begin{tabular}{|c|c|c|c|}
\hline $\begin{array}{l}\text { Functioning under natural regimes of } \\
\text { well-conserved communities }\end{array}$ & Savannas & Forests & References \\
\hline Seed rain & Moderate & High & $\begin{array}{l}\text { Myers \& Harms (2011) } \\
\text { Piotto et al. (2019) }\end{array}$ \\
\hline Belowground resilience & Very high & Low & $\begin{array}{l}\text { Vesk \& Westoby (2004) } \\
\text { Ferreira et al. (2015) }\end{array}$ \\
\hline Reliance on soil seed banks & Low & Moderate to high & $\begin{array}{l}\text { Skoglund (1992) } \\
\text { Salazar et al. (2011) }\end{array}$ \\
\hline Natural regeneration & Very high & High & $\begin{array}{l}\text { Veldman et al. (2015b) } \\
\text { Crouzeilles et al. (2017) }\end{array}$ \\
\hline \multicolumn{4}{|l|}{ Restoration interventions } \\
\hline Tree planting & Discouraged & $\begin{array}{l}\text { Strongly } \\
\text { encouraged }\end{array}$ & $\begin{array}{l}\text { Rodrigues et al. (2009) } \\
\text { Veldman et al. (2015a) } \\
\text { Fernandes et al. (2016a) }\end{array}$ \\
\hline Seed sowing & Encouraged & Encouraged & $\begin{array}{l}\text { Engel \& Parrota (2001) } \\
\text { Silva et al. (2015) }\end{array}$ \\
\hline Removal of fertilizers & $\begin{array}{l}\text { Strongly } \\
\text { encouraged }\end{array}$ & Discouraged & $\begin{array}{l}\text { Campoe et al. (2014) } \\
\text { Silva et al. (2015) }\end{array}$ \\
\hline Use of fire & Encouraged & Discouraged & $\begin{array}{l}\text { Pivello (2011) } \\
\text { Buisson et al. (2018) }\end{array}$ \\
\hline Use of large herbivores & Encouraged & Discouraged & $\begin{array}{l}\text { Venter et al. (2017) } \\
\text { Buisson et al. (2018) }\end{array}$ \\
\hline
\end{tabular}


way by diminishing or eliminating the need for active interventions in cases when these capacities are high (Suding 2011).

The restoration of non-forest ecosystems, such as grasslands and savannas has been a challenge since most past restoration efforts have been focused on forests (Bond \& Parr 2010). Furthermore, some restoration practices commonly used to reverse forest ecosystem degradation cannot be directly applied to other ecosystems as they can jeopardize their biodiversity and ecosystem functioning (Veldman et al.2015a). One of these inappropriate and widely applied practices is planting trees in ecosystems that were originally with open vegetation (Fernandes et al. 2016a, Parr et al. 2014). This practice, known as afforestation, can lead to the loss of grassland species because of different ecosystem functioning and both direct and indirect species interference (e.g. Buisson et al. 2018, Fernandes et al. 2016a). Moreover, the use of exotic species has also been applied to restore grasslands and savannas even though it can change native community composition and ecosystem dynamics (Fernandes et al. 2016c, Modna et al. 2010, Santilli \& Durigan 2014). Hence, it is vital that conservation and restoration solutions be appropriately and specifically designed for each ecosystem type (Buisson et al. 2018).

The Cerrado is a Brazilian biome dominated by savanna vegetation type, which made it being widely known as the 'Brazilian savanna'. However, the Cerrado also includes a variety of ecosystems such as seasonally dry forests and grasslands (Fernandes et al. 2016b, Ribeiro \& Walter 1998, Sano et al. 2008). Historically, the Cerrado has been misrecognized as a severely degraded vegetation (Schmidt et al. 2019, Veldman et al. 2015b) and has been largely neglected as a conservation and restoration priority (Guerra et al. 2020, Overbeck et al. 2015) despite of the fact that it is a global biodiversity hotspot (Myers et al. 2000). The Cerrado has lost almost half of its native vegetation cover mainly due to livestock and agriculture land use (Scaramuzza et al. 2017). The open-vegetation and flat topography of most Cerrado areas made the biome an easy target for agribusiness. On the other hand, the Cerrado hosts more than 300,000 animal species and above 13,000 plant species (Fernandes et al. 2016b), with many being endemic (e.g., $44 \%$ of the plant species of the Cerrado are endemic to it; Klink \& Machado 2005).

The threats to Cerrado biodiversity are expected to increase since further vegetation loss is likely to occur. This can be expected since the Brazilian federal government keeps encouraging agricultural expansion as a way to promote economic development (Rajão et al. 2020, Strassburg et al. 2017, Vieira et al. 2017). Furthermore, if Brazilian law 12.651, which establishes norms for native vegetation protection (Brasil 2012a), were properly enforced, a potential legal loss of native habitats is expected to occur resulting in unprecedented species extinction and water supply crisis (Vieira et al. 2017). Preventing the loss of biodiversity and ecosystem services in the Cerrado is not an easy task but restoration incentives are key for its achievement. Currently, two important instruments among the political incentives regarding restoration are the national plan for recovery of native vegetation (PLANAVEG Ministério do Meio Ambiente 2017) and the rural environmental register (CAR - Brasil 2012b). The former aims to articulate and integrate actions to recover native vegetation of at least 12 million hectares by 2030, while the later has the purpose of creating a database to integrate environmental information of rural properties. This database will be important for assisting economic and environmental planning as well as for supervising the destruction of native 
vegetations. Despite these political incentives, many restoration studies and practices that have been applied to the Cerrado have their roots in restoration practices developed for forest ecosystems, usually aiming to afforest an area that never had forest to begin with (Fernandes et al. 2016a).

The success of restoration initiatives in the Cerrado will depend upon our ability to efficiently and effectively implement sound ecological restoration programs (Bustamante et al. 2019, Fernandes et al. 2016c, McDonald et al. 2016). Therefore, it is imperative to know if the knowledge present in the literature can actually promote ecological restoration regardless of political, social, and economic issues. Considering a hypothetical scenario in which there is appropriate investment in restoration activities, we are asking: is there enough scientific knowledge available that can inform how restoration practices should be conducted in the Cerrado? We aimed to respond to this question through a comprehensive systematic review of restoration studies among all Cerrado vegetation types. In our review, we assume that restoration initiatives and management strategies must differ among different ecosystems because of their specific ecological features, functioning, and provision of ecosystem services. Our purpose is to draw a panorama of Cerrado restoration activities by summarizing what is known from previous studies and then provide some recommendations for future studies and restoration practices. Specifically, we address the following questions: (a) based on the literature, how have restoration practices and studies been performed in the Cerrado? (b) are the identities and growth forms of plant species taken into account?

\section{MATERIALS AND METHODS}

\section{Definitions}

Here, we adopted "restoration" to refer to the field of study of restoration as a whole and tried to cover all studies that aimed to recover a degraded, damaged or destroyed ecosystem by improving its state and/or functionality (McDonald et al. 2016). Studies of recovery, rehabilitation, recomposition, revegetation or reforestation were considered as ecological restoration projects if their main goal was the reestablishment of the native ecosystem (McDonald et al. 2016). Different ecological restoration approaches can be adopted depending on ecosystem degradation level and resilience capacity (Buisson et al. 2018, Chazdon 2008). Therefore, we considered that ecological restoration projects had a "natural regeneration approach" when the causal factors of degradation were removed so as to allow the natural increase in the number of individual plants, and considered an "assisted regeneration approach" when active intervention was performed (e.g., control of exotic species, reintroductions, habitat conditioning, reapplying ecological disturbance regimes) (McDonald et al. 2016).

The Cerrado includes a wide range of vegetation types, for which we followed the classifications of Ribeiro \& Walter (1998) and Oliveira-Filho \& Ratter (2002). These classifications consider old-growth savanna to be the dominant vegetation of the Cerrado (sensu Veldman et al. 2015b), which comprises a gradient of tree cover density from open grasslands to dense woodlands. Cerrado sensu lato includes the following vegetation types: campo limpo (grassland with no trees), campo sujo (grassland with a few shrubs and small trees), campo cerrado (tree cover of 5-20\%, average tree height of 2-4m, no continuous canopy), cerrado sensu stricto (tree cover of $20-50 \%$, average 
tree height of 3-6m, no continuous canopy) and cerradão (tree cover of 50-90\%, average tree height of 8-15m). When studies mention only "Cerrado" we classified it as cerrado sensu lato as it usually comprises all types of old-growth savanna vegetation. Moreover, we also considered the other vegetation types of the Cerrado phytogeographic domain, namely: riparian forest - forested vegetation found alongside streams and rivers (tree cover of 50$95 \%$, average tree height of $20-30 \mathrm{~m}$ ); vereda wetland areas; mata seca - seasonally dry forests associated to fertile soils (tree cover of 50-95\%, average tree height of $15-25 \mathrm{~m}$ ); and quartzitic rupestrian grassland and ironstone outcrops or canga - grassland vegetation with few shrubs and small trees associated with quartzitic soils or ferruginous soils, respectively.

\section{Literature review}

To compile the state of the art of restoration in the Cerrado, we performed a systematic literature review that considered all experimental and observational studies published on the subject from 1975 to 2017. We selected journal articles, theses and dissertations in English and Portuguese that comprised relevant and applied information on the restoration of any Cerrado vegetation type. We performed searches using three groups of keywords in different databases to include all the available literature about the subject: Web of Science (a worldwide database), Scielo (a Latin American database) and the Brazilian theses and dissertation bank of the Brazilian funding and regulatory agency (Coordenação de Aperfeiçoamento de Pessoal de Nivel Superior - CAPES). We submitted all publications found in our searches to an initial screening that examined only the title and abstract. We then conducted a second screening by carefully analyzing their integral text. We excluded publications that (i) did not have information about the vegetation of the study area; (ii) did not have focus and conclusions on recovering a degraded ecosystem within the "restoration" definition adopted here (see section Definitions); and (iii) did not have the full text available. From each of the remaining publications, we extracted information on accessibility and research characteristics (Table II). Publication accessibility is important for exchanging information and including the Cerrado in the international panorama of savannas. Moreover, we wanted to understand where and which vegetation types have been restored and to verify how research has been done considering the evaluation of outcomes. We classified the publications according to their restoration aim (Table II), as we wanted to focus on publications that had the overall intention of recovering the native ecosystem. This classification allowed us to determine the ecological restoration approach used and to analyze the plant species that have been used in assisted regeneration of the Cerrado.

\section{Plant Database}

We created a plant database in order to know which plant species have been used to restore the Cerrado. We considered whether the selected publications had an ecological restoration objective and adopted an assisted regeneration approach, thus, we recorded all plant species that were chosen and actually planted in a degraded area. Furthermore, when the information was available, we also included publications with an ecological restoration objective that did their research at a site already submitted to active restoration. We then obtained the following complementary information for the plant species from Reflora virtual herbarium (Flora do Brasil 2020): family, growth form, and if the plant was native or exotic to the Cerrado biome. Moreover, for the 15 most used plant species, we 
Table II. Information extracted from the selected publications.

\begin{tabular}{|c|c|}
\hline Information assessed & Description \\
\hline Publication accessibility & $\begin{array}{l}\text { The type of publication (journal article or dissertation/thesis), language used } \\
\text { (English or Portuguese) and the article's Journal }\end{array}$ \\
\hline Geographical location & Where the research was conducted (coordinates) \\
\hline Native vegetation type & $\begin{array}{c}\text { The native Cerrado vegetation type that is the reference ecosystem for the } \\
\text { restoration (see section Definitions) }\end{array}$ \\
\hline Previous Land use & $\begin{array}{c}\text { The previous land use type of the area on restoration (agriculture, abandoned } \\
\text { pasture, mining, etc.) }\end{array}$ \\
\hline Monitoring activity & If the research had any monitoring activity and how frequently it was done \\
\hline Analysis & $\begin{array}{l}\text { If the study used any statistical analyses (frequentist, index, modelling) or not } \\
\text { (descriptive or review) }\end{array}$ \\
\hline Restoration objective/intention & $\begin{array}{c}\text { If the research had propose an "ecological restoration" (see section } \\
\text { Definitions) objective, or intention, or if it clearly did not intend to recover the } \\
\text { native ecosystem }\end{array}$ \\
\hline Restoration approach & $\begin{array}{l}\text { The restoration approach (see section Definitions) used on the publications } \\
\text { that had a "ecological restoration" objective or perspective }\end{array}$ \\
\hline
\end{tabular}

recorded more detailed information about the Cerrado vegetation type in which they naturally occur (Flora do Brasil 2020, Lorenzi 1992). We used this detailed information to evaluate whether plant species were used to restore their native vegetation type or other vegetation types.

\section{Data analyses}

\section{Restoration practices and studies in the Cerrado}

We used publication quantity or number of studies to evaluate information accessibility, monitoring activity and analyses used, as well as to categorize the study objective/intention and the restoration approach adopted in cases of studies that aimed at ecological restoration. The other analyses were done considering research effort rather than the number of studies since some publications evaluated more than one restoration practice (e.g. used more than one technique, did more than one type of monitoring or evaluated more than one restoration site). We used the 'ggplot2' package of R software 3.5.0 (R Core Team 2017) to make bar-plot graphs and present the following characteristics of the research: native vegetation type; causes of degradation and analysis used. The geographical location of the research was used to generate a heatmap to show where the majority of the research about Cerrado restoration have taken place.

\section{Plant species used in ecological restoration of Cerrado vegetation types}

We synthesized the information of the plant database in order to evaluate the proportion of native and exotic species used in Cerrado restoration reserch. We also calculated the proportion of trees and shrubs used to 
determine whether the proportion of plant species growth forms used in the restoration of a certain vegetation type corresponded to the original proportion (according to Ribeiro \& Walter (1998) and Oliveira-Filho \& Ratter (2002) definitions). We used the information about the 15 most used plant species to evaluate whether plant species identity was taken into consideration in Cerrado restoration. To do this, we compared information about the vegetation types in which plant species originally occur to the vegetation types in which they were used for restoration. When cerrado sensu lato appeared in Reflora virtual herbarium as a vegetation type that a plant species naturally occurrs, we considered that the species could be used in resoration of campo limpo, campo sujo, campo cerrado, cerrado sensu stricto and cerradão.

\section{RESULTS}

\section{Restoration practices and studies in the Cerrado}

We selected a total of 145 publications to assess the Cerrado restoration panorama throughout the 42 years considered (Supplementary Material - Table SI). The majority of the selected publications were in Portuguese (64\%) while 33\% of the publications were in English and only 3\% were in both languages (theses or dissertations with Portuguese and English chapters). We also found a great proportion of dissertations and theses (41\%) while most of the selected journal articles were published in Brazilian journals (59\%). Only three theses and four dissertations selected had some content published in journal articles and were considered only one time for research effort analyses. Nonetheless, the number of publications in peer-reviewed as well as in international journals has been increasing over time, but mainly in the last five years.
We found that research efforts were highly concentrated in the Federal District and in specific locations of the states of Goiás, São Paulo and Minas Gerais (Figure 1). There was a predominance of research efforts involving a few research groups from some public institutions, such as the Universidade de Brasilia (UnB), Universidade Estadual de Campinas (Unicamp) and Escola Superior de Agricultura Luiz de Queiroz (ESALQ-USP). Furthermore, most of the publications had an ecological restoration intention (72\%) while only several publications did not have such intention (28\%) and aimed to practice afforestation, establish agroecosystems or rehabilitate degraded pastures to maintain agribusiness activities (Table III). We found that among the publications with ecological restoration intention, the assisted regeneration approach (44.8\%) was more common than the natural regeneration approach (18.1\%). There were four publications that included both approaches (3.8\%) and several publications did not perform field experiments in degraded areas (33.3\%). Furthermore, we found that most publications employed some quantitative analysis (84.1\%) while $9.7 \%$ of them were descriptive and $5.5 \%$ were reviews. The most common type of statistical analysis used was frequentist (72.4\%) while the less used was modelling (4.9\%). There was one publication that used map overlay, and so was not considered as statistical analysis, descriptive or review (Simões et al. 2002).

We found that much of the research done in the publications did not specify the vegetation type that was going to be restored, which made cerrado sensu lato (31.2\%) the most common vegetation type targeted by restoration research efforts. We also found that campo limpo did not appear in any research while many other vegetation types were relatively underrepresented in Cerrado restoration research reported in the literature: campo sujo 


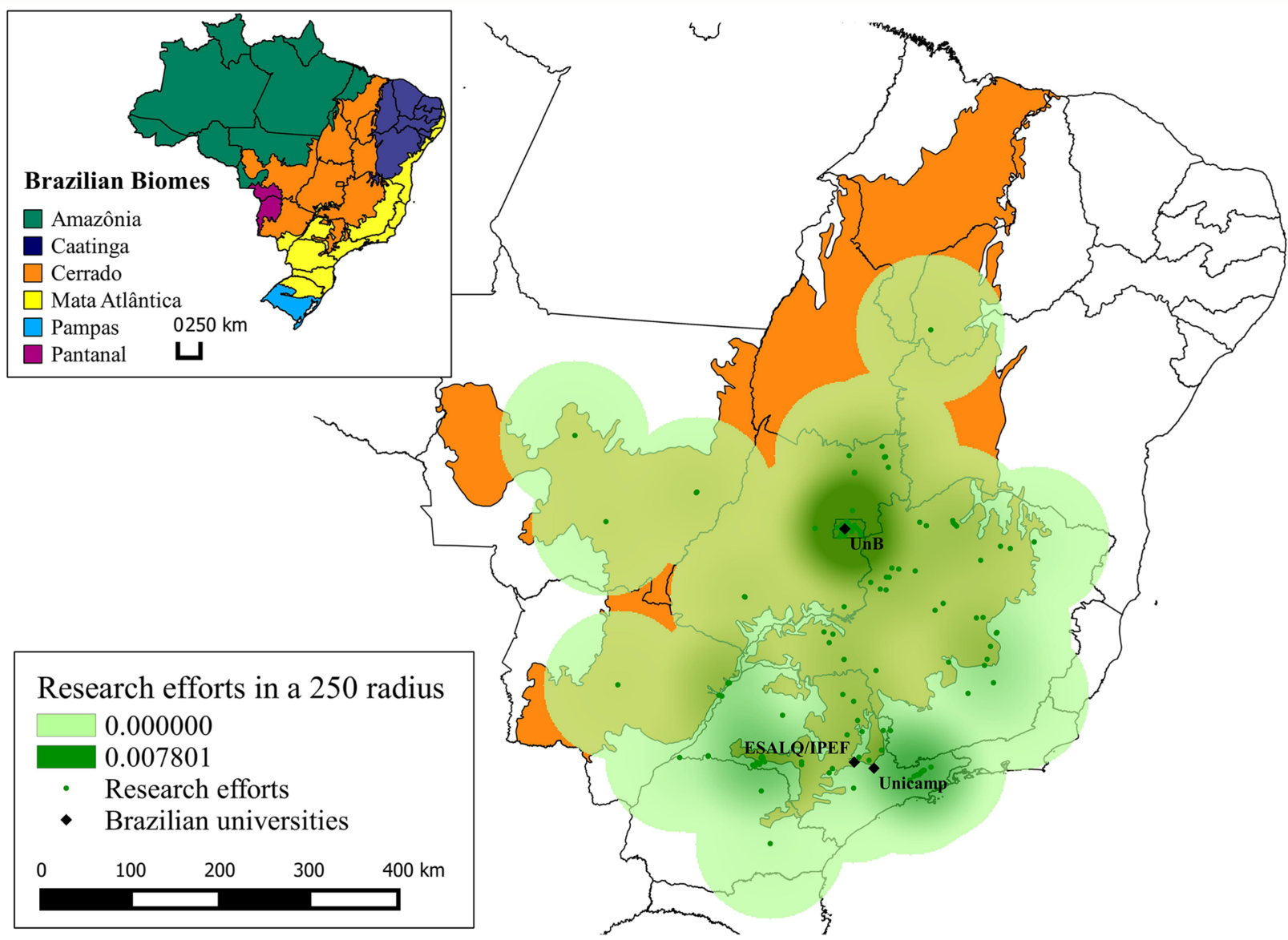

Figure 1. The concentration of research efforts of Cerrado restoration is represented in a kernel map. The intensity of green circles positively increases with the number of research efforts. The exact location of the research are also pointed in the map. Some research groups of public universities are pointed: Universidade de Brasilia (UnB), Universidade Estadual de Campinas (Unicamp) and Escola Superior de Agricultura Luiz de Queiroz (ESALQUSP). *Some publications were not shown in the map: two publications that focused in the whole Cerrado; six publications that generally focused on restoration of native ecosystems of Brazil; and three publications conducted in Goiás and Tocantins states that did not provide specific geographic location.

(2.1\%), ironstone outcrop (2.1\%) vereda (2.8\%), quartzitic rupestrian grassland (3.5\%), campo cerrado (3.5\%), cerradão (4.9\%), mata seca (5.6\%), cerrado sensu stricto (20\%) and riparian forest $(24.3 \%)$. We did not categorize 12 of the publications into vegetation types because they were either theoretical, focused on the Cerrado biome or did not mention any vegetation type. We considered a publication to have a focus on the Cerrado biome when it clearly made reference to the geographic region or to large scale restoration. Moreover, we evaluated the causes of degradation in restoration research of the selected publications and found the main causes to be livestock (33.3\%) and agriculture (22.5\%), followed by hydroelectric (10.2\%), quarry (8.2\%), mining (7.5\%) and urban (2\%) impacts. We found one study that investigated the impact of alkaline industrial waste, and could not find information about previous land use for $15.6 \%$ of the publications. Additionally, we did not apply 'land use' categorization for 24 of the publications as they were theoretical. Furthermore, we found that $42 \%$ of Cerrado restoration publications did 
Table III. The objectives of the selected publications

\begin{tabular}{|c|c|c|c|}
\hline $\begin{array}{l}\text { Ecological } \\
\text { Restoration } \\
\text { Intention }\end{array}$ & $\begin{array}{l}\text { Research Main } \\
\text { Objective }\end{array}$ & $\begin{array}{l}\text { Number of } \\
\text { publications }\end{array}$ & Description \\
\hline \multirow{4}{*}{$\begin{array}{l}\text { Yes } \\
(72 \%)\end{array}$} & $\begin{array}{l}\text { Ecological restoration: } \\
\text { assisted regeneration } \\
\text { approach }\end{array}$ & $\begin{array}{c}47 \\
(44.8 \%)\end{array}$ & $\begin{array}{l}\text { Experimental research that aimed to restore* a } \\
\text { degraded area through assisted regeneration approach }\end{array}$ \\
\hline & $\begin{array}{l}\text { Ecological restoration: } \\
\text { natural regeneration } \\
\text { approach }\end{array}$ & $\begin{array}{c}19 \\
(18.1 \%)\end{array}$ & $\begin{array}{l}\text { Experimental research that aimed to restore a } \\
\text { degraded area through natural regeneration approach }\end{array}$ \\
\hline & $\begin{array}{l}\text { Ecological restoration: } \\
\text { natural and assisted } \\
\text { regeneration approaches }\end{array}$ & $\begin{array}{c}4 \\
(3.8 \%)\end{array}$ & $\begin{array}{c}\text { Experimental research that aimed to restore a } \\
\text { degraded area exploring both approaches: natural and } \\
\text { assisted regeneration }\end{array}$ \\
\hline & $\begin{array}{l}\text { Ecological restoration: } \\
\text { no field experiments }\end{array}$ & $\begin{array}{c}35 \\
(33.3 \%)\end{array}$ & $\begin{array}{c}\text { Theoretical and experimental research that aimed to } \\
\text { investigate ecological restoration (ie. reviews, in vitro } \\
\text { experiments, control of invasive species at a restored } \\
\text { area...) }\end{array}$ \\
\hline \multirow{4}{*}{$\begin{array}{l}\text { No } \\
(28 \%)\end{array}$} & Rehabilitation & $\begin{array}{c}19 \\
(47.5 \%)\end{array}$ & $\begin{array}{l}\text { Theoretical and experimental research that aimed to } \\
\text { investigate the rehabilitation of degraded areas with } \\
\text { no intention to reestablish the native ecosystem }\end{array}$ \\
\hline & Agroecosystem & $\begin{array}{c}10 \\
(25 \%)\end{array}$ & $\begin{array}{l}\text { Theoretical and experimental research that aimed for } \\
\text { the establishment of agro ecosystems }\end{array}$ \\
\hline & Recovery & $\begin{array}{c}9 \\
(22.5 \%)\end{array}$ & $\begin{array}{c}\text { Experimental research that aimed to recover a } \\
\text { degraded area but did not intent to reestablish the } \\
\text { native ecosystem }\end{array}$ \\
\hline & Afforestation & $\begin{array}{c}2 \\
(5 \%)\end{array}$ & $\begin{array}{c}\text { Theoretical and experimental about afforestation } \\
\text { practice }\end{array}$ \\
\hline
\end{tabular}

*include recovery, rehabilitation, recomposion and revegetation research with an ecological restoration purpose

not perform any monitoring activity or it was not relevent to them (theoretical research) and only $0.7 \%$ of the publications did not present any information about monitoring. Even though most publications perfromed some monitoring activity, we did not find any monitoring pattern and $2.3 \%$ of the research did not inform the periodicity of monitoring.

\section{Plant species used in ecological restoration of Cerrado vegetation types}

A total of 419 plant species were used in assisted ecological restoration of degraded Cerrado areas (Table S2), however, only 166 of them were used in more than one research. The richness of used plant species varied among Cerrado vegetation types: campo cerrado (10 plant species), cerradão (88 plant species), cerrado sensu lato (68 plant species), cerrado sensu stricto (179 plant species), ironstone outcrop (2 plant species), quartzitic rupestrian grassland (26 plant species), riparian forest (191 plant species), mata seca (21 plant species) and vereda (72 plant species). We excluded 60 plant species from plant analysis because we did not have enough information about them. Most of the plant species used were native to the Cerrado biome (86.7\%) and most had a tree growth form (Table IV). The concern about the proportion of growth forms used for ecological restoration 
varied according to Cerrado vegetation types (Tables IV-VI). We found a prevalence of shrubs and trees being used for all restored vegetation types (except for campo cerrado); thus, some vegetation originally characterized by tree layer dominance (riparian forest and mata seca) were mainly restored using tree plants. On the other hand, restoration of some vegetation types, such as quartzitic rupestrian grassland and vereda, did not respect the original vegetation structure and characteristics (Oliveira-Filho \& Ratter 2002, Ribeiro \& Walter 1998). Furthermore, we found that the 15 most used plant species (Table VII) were all native to the Cerrado biome and that $70.8 \%$ of the assisted restoration research used at least one of them. These 15 species were used to restore a range of Cerrado vegetation types (cerradão, cerrado sensu lato, cerrado sensu stricto, quartzitic rupestrian grassland, riparian forest, mata seca and vereda) including those in which they do not originally occur (quartzitic rupestrian grassland, riparian forest, mata seca and vereda).

\section{DISCUSSION}

Our review indicates that the increasing interest and/or awareness towards restoration of the Cerrado has not followed the recommendations established by the ecological knowledge available in the literature (Fernandes et al. 2016c, Kollmann et al. 2016, McDonald et al. 2016). We found that many studies and practices done in the Cerrado are rooted in practices commonly used for forest restoration using tree species; therefore representing cases of afforestation (Fernandes et al. 2016a). Furthermore, we found that plant species have been used regardless of the reference ecosystem when we consider the original occurrence and proportion of plant species growth forms. This finding highlights the need to clearly define the reference ecosystem and respect its characteristics while planning and performing restoration of the Cerrado. Moreover, research has focused mainly on two Cerrado vegetation types (cerrado sensu stricto and riparian forest) and were associated mainly with agribusiness impacts. We also found that studies still lack a systematic form of evaluating the outcomes of restoration as most have employed monitoring in a case-specific way.

Table IV. The plant species growth form used in assisted regeneration of the Cerrado biome.

\begin{tabular}{|c|c|c|c|c|c|c|c|c|}
\hline \multirow{2}{*}{ Plant growth form } & \multicolumn{6}{|c|}{ Diversity of plant species (unique record) } & \multicolumn{4}{|c|}{ Total plant species used } \\
\cline { 2 - 10 } & Native & Exotic & Total & $\%$ & Native & Exotic & Total & $\%$ \\
\hline Climbing & 6 & 1 & 7 & 1.7 & 7 & 1 & 8 & 0.8 \\
\hline Climbing-shrub & 6 & 0 & 6 & 1.4 & 9 & 0 & 9 & 0.9 \\
\hline Climbing-shrub-tree & 4 & 0 & 4 & 0.9 & 4 & 0 & 4 & 0.4 \\
\hline Herb & 36 & 6 & 42 & 10 & 47 & 6 & 53 & 5.3 \\
\hline Herb-shrub & 5 & 0 & 5 & 1.2 & 6 & 0 & 6 & 0.6 \\
\hline Shrub & 46 & 3 & 49 & 11.7 & 57 & 4 & 61 & 6.1 \\
\hline Shrub-tree & 86 & 6 & 92 & 21.9 & 224 & 6 & 230 & 23 \\
\hline Tree & 174 & 40 & 214 & 51.1 & 562 & 67 & 629 & 62.9 \\
\hline
\end{tabular}


Therefore, although we have gained some insights and perspectives into the restoration of the Cerrado, successful restoration efforts for many Cerrado vegetation types will depend on applying available ecological knowledge to restoration practices. Furthermore, the improvement of knowledge related to natural regeneration (Crouzeilles et al. 2017) and dynamics, as well as to the cultivation of native plant species, should be encouraged (Fernandes et al. 2016c).

The existence of research groups focused on Cerrado restoration is fundamental for supporting upscale ecological restoration and conservation. However, we found that studies were concentrated among only three research groups. It is crucial to expand these research groups and increase collaboration networks between them to move Cerrado restoration forward and encompass all vegetation types (De Montjoye et al. 2014). We advocate for overseas collaborations since restoration practices and ideas from other savannas with similar structure and function could be applied to the Cerrado. This exchange of ideas could only be made possible if scientific studies are accessible and done in a systematic form. In this context, we found that $42 \%$ of the publications were dissertations and theses with more limited access and which could have their information altered/improved

Table V. The frequency of plant species growth forms used in ecological restoration of Cerrado vegetation types: CC (campo cerrado), C (cerradão), Csl (cerrado sensu lato), Css (cerrado sensu stricto), IO (ironstone outcrop), MS (mata seca), QRG (quartzitic rupestrian grassland), RF (riparian forest), and V (vereda). Plant species are classified according to their occurrence in the Cerrado biome (native or exotic).

\begin{tabular}{|c|c|c|c|c|c|c|c|c|c|c|}
\hline Cerrado Biome & Growth form & & & Csl & Css & & & QRG & RF & v \\
\hline \multirow{8}{*}{ Native } & Climbing & & & 2 & 2 & & & 1 & 1 & 2 \\
\hline & Climbing-shrub & 1 & 1 & & 6 & & 1 & & & \\
\hline & Climbing-shrub-tree & & 1 & & & & & & 2 & 1 \\
\hline & Herb & 12 & & 2 & 12 & & & 7 & 4 & 10 \\
\hline & Herb-shrub & & 1 & 2 & 2 & & & 1 & & \\
\hline & Shrub & & 4 & 5 & 24 & 2 & 1 & 11 & 8 & 3 \\
\hline & Shrub-tree & & 31 & 29 & 79 & & 2 & 1 & 71 & 11 \\
\hline & Tree & & 54 & 41 & 195 & & 18 & 5 & 207 & 42 \\
\hline \multirow{8}{*}{ Exotic } & Climbing & & & & & & & & & \\
\hline & Climbing-shrub & & & & & & & & & \\
\hline & Climbing-shrub-tree & & & & & & & & & \\
\hline & Herb & 1 & & 4 & & & & & 1 & \\
\hline & Herb-shrub & & & & & & & & & \\
\hline & Shrub & & 2 & & & & & & 1 & \\
\hline & Shrub-tree & & 1 & & & & & & 4 & 1 \\
\hline & Tree & & 10 & & 4 & & 2 & & 45 & 6 \\
\hline
\end{tabular}


through the peer-review process (only 15\% of dissertations and $9 \%$ of these were eventually published in scientific journals). Moreover, the prevalence of the Portuguese language and Brazilian journal publications found for restoration in the Cerrado also results in limited access. However, we acknowledge a current increase in international publications and highlight that researchers should continue to be encouraged to publish their data in English and in international journals to facilitate access and interchange of ideas and experiences.

\section{Restoration practices and studies in the Cerrado}

Most studies had an ecological restoration intention and used the assisted regeneration approach dispite of the higher costs when compared to the natural regeneration approach. The major issues for research efforts were the unawareness of the differences and specificities of Cerrado vegetation types and the lack of systematic monitoring. Although a variety of vegetation types compose the Cerrado biome, we found that most of them only have a few reported restoration efforts (e.g. campo cerrado, vereda, campo sujo, campo limpo, quartzitic rupestrian grassland and ironstone outcrop). We also found that most of the research (31.3\%) did not even mention what vegetation type was intended to be restored. Most restoration efforts were monitored but monitoring activities were done in a case-specific way. Futhermore, research efforts to restore the Cerrado were unevenly distributed and mostly related to restoration after livestock and agriculture impacts, and concentrated in few research groups from Brazilian public universities. It is not surprising that these research groups are located in areas that were initially devasted for agribusiness and currently have high population densities. Besides, most of the studies were quantitatively analyzed while a modelling approach was rarely used. Although modelling may not be appropriate for many studies, we highlight that it might be worthwhile when

Table VI. The tree cover that characterize each of the Cerrado vegetation type and the proportion of trees and shrub-trees found in ecological restoration research (assisted regeneration approach). The trees of restoration research comprises all trees used in relation to the other growth forms while the shrub-trees of restoration research comprises all plant species with shrub, shrub-tree and tree growth forms used. The Cerrado vegetation types are CC (campo cerrado), C (cerradão), Css (cerrado sensu stricto), 10 (ironstone outcrop), MS (mata seca), QRG (quartzitic rupestrian grassland), RF (riparian forest) and V (vereda).

\begin{tabular}{|c|c|c|c|}
\hline Cerrado vegetation type & Original tree cover (\%) & $\begin{array}{c}\text { Shrub-trees of } \\
\text { restoration research (\%) }\end{array}$ & $\begin{array}{c}\text { Trees of restoration } \\
\text { research (\%) }\end{array}$ \\
\hline CC & $5-20$ & 0 & 0 \\
\hline C & $50-90$ & 97.1 & 61 \\
\hline CSS & $20-50$ & 93.2 & 61.4 \\
\hline IO & $5-20$ & 100 & 0 \\
\hline MS & $50-95$ & 95.8 & 83.3 \\
\hline QRG & $5-20$ & 65.4 & 19.2 \\
\hline RF & $50-95$ & 97.7 & 73.2 \\
\hline V & $5-10$ & 82.9 & 63.1 \\
\hline
\end{tabular}


planning landscape designs for ecological restoration (Couto et al. 2011, Molin et al. 2018) to predict management effects (Firn et al. 2010) like those related to different fire managements (Alvarado et al. 2017) and invasive species control (Barbosa et al. 2018).

The differences and specificities of Cerrado vegetation types should be considered in restoration research and practices (Fernandes et al. 2016b, c); however, we did not find such awareness. It is imperative to clearly determine the vegetation type to be restored but many efforts only used 'cerrado' as a reference ecosystem. Sometimes it was even diffult to determine if the research was making reference to cerrado sensu lato or the Cerrado biome. Moreover, the diversity of the Cerrado (Fernandes et al. 2016b, Oliveira-Filho \& Ratter 2002, Ribeiro \& Walter 1998) should to be included in restoration efforts and there is urgent need to raise concern about insufficient efforts towards different vegetation types. We did not find any research on ecological restoration in campo limpo and most of the Cerrado vegetation types, especially those dominated by herbaceous plant species, had just a few research efforts. This result should be taken with caution, as it would be important to relate this to the area they cover (e.g., vereda and canga cover much less area); their biodiversity (currently known to be high in quartizitic rupestrian grassland - see Silveira et al. 2016) and their level of degradation. However, these aspects are seldom studied and no good numbers are yet available. We suggest future studies should map and compute these aspects, fostering a more precise discussion. Besides, the low attention given to some vegetation types, such as campo limpo, campo sujo, campo cerrado, quartzitic rupestrian grassland and ironstone outcrops, could be related to limited or scarce knowledge on natural regeneration (Silveira et al. 2016, but see Luz et al. 2018) and the lack of knowledge about requirements of native species cultivation (De Souza et al. 2017, Fernandes et al. 2016c). The difficulties in recognizing and determining each vegetation type, and the fact that restoration has been historically attached to forest ecosystems and tree usage, also hamper attempts to ecologically restore the natural heterogeneity of the Cerrado (see Fernandes et al. 2020).

Cerrado restoration efforts were not only concentrated in a few vegetation types but also had a geographic bias. Restoration efforts were associated with few research groups and with agribusiness impacts. The concentration of restoration efforts in areas impacted by agribusiness may be related to the rehabilitation of land quality to improve agribusiness profit (Laurance et al. 2014, Silva et al. 2017). Nevertheless, we found that most of the publications aimed to reestablish the native ecosystem. This finding may indicate that environmental legislation is playing a role in stimulating ecological restoration as landowners are investing to restore natural ecosystems, especially in areas near water courses (Sparovek et al. 2012). Assisted regeneration was the most used approach in Cerrado restoration efforts but it may not be financially viable for many landowners or at large scales. Therefore, prioritizing natural regeneration in areas with a low level of degradation or near native ecosystem patches could allow limited budgets to be redirected to other areas and maximize restoration efforts (Chazdon \& Guariguata 2016). However, this strategy may not be feasible if the ecosystem achieves ecological thresholds that do not allow their natural recovery anymore. In cases when passive recovery is ecologically impossible or when frequent endogenous disturbances have not naturally been established, active interventions should be adopted (Buisson et al. 2018). Moreover, the 
Table VII. The plant species most used in ecological restoration research of the Cerrado vegetation types. The Cerrado vegetation types are CL (campo limpo), C (cerradão), Csl (cerrado sensu lato), Css (cerrado sensu stricto), MS (mata seca), QRG (quartzitic rupestrian grassland), RF (riparian forest) and V (vereda).

\begin{tabular}{|c|c|c|c|c|c|}
\hline Plant species & Common name & Family & $\begin{array}{l}\text { Growth } \\
\text { form }\end{array}$ & $\begin{array}{c}\text { Naturally } \\
\text { occurrence in } \\
\text { Cerrado Biome }\end{array}$ & $\begin{array}{l}\text { Vegetation type of } \\
\text { the restoration site } \\
\text { (number of } \\
\text { studies) }\end{array}$ \\
\hline $\begin{array}{c}\text { Anadenanthera } \\
\text { colubrina (Vell.) } \\
\text { Brenan }\end{array}$ & $\begin{array}{c}\text { Angico, angico- } \\
\text { branco, cambuí- } \\
\text { angico }\end{array}$ & Fabaceae & $\begin{array}{l}\text { shrub or } \\
\text { tree }\end{array}$ & $\begin{array}{l}\mathrm{C} \\
\mathrm{CSl} \\
\mathrm{MS} \\
\mathrm{RF}\end{array}$ & $\begin{array}{l}\operatorname{Csl}(2) \\
\operatorname{CsS}(5) \\
M S(1) \\
\operatorname{RF}(3) \\
\mathbf{v}(\mathbf{1})\end{array}$ \\
\hline $\begin{array}{c}\text { Anadenanthera } \\
\text { falcata (Benth.) } \\
\text { Speg. }\end{array}$ & Angico do cerrado & Fabaceae & $\begin{array}{l}\text { shrub or } \\
\text { tree }\end{array}$ & Csl & $\begin{array}{l}\operatorname{C}(2) \\
\operatorname{Csl}(1) \\
\operatorname{Css}(1) \\
\operatorname{RF}(6)\end{array}$ \\
\hline $\begin{array}{c}\text { Astronium } \\
\text { fraxinifolium Schott }\end{array}$ & Gonçalo-alves & Anacardiaceae & tree & Csl & $\begin{array}{l}\operatorname{CsS}(4) \\
\operatorname{MS}(1) \\
\operatorname{RF}(6)\end{array}$ \\
\hline Cedrela fissilis Vell. & $\begin{array}{c}\text { Cedro, cedro- } \\
\text { batata, cedro- } \\
\text { cetim, cedro-da- } \\
\text { várzea }\end{array}$ & Meliaceae & tree & Csl & $\begin{array}{l}C(2) \\
\operatorname{CsS}(4) \\
\operatorname{RF}(5) \\
V(1)\end{array}$ \\
\hline $\begin{array}{c}\text { Copaifera } \\
\text { langsdorffii Desf. }\end{array}$ & $\begin{array}{l}\text { Copaíba, } \\
\text { copaibeira, pau- } \\
\text { de-óleo }\end{array}$ & Fabaceae & tree & $\begin{array}{l}\text { Csl } \\
\text { QRG } \\
\text { RF }\end{array}$ & $\begin{array}{c}\text { C (2) } \\
\text { Csl (3) } \\
\text { CsS (8) } \\
\text { MS (1) } \\
\operatorname{RF~(8)~} \\
\text { V (1) }\end{array}$ \\
\hline Dipteryx alata Vogel & $\begin{array}{l}\text { Baru, cumbaru, } \\
\text { cumaru }\end{array}$ & Fabaceae & tree & $\begin{array}{l}\mathrm{CSl} \\
\mathrm{RF}\end{array}$ & $\begin{array}{l}\operatorname{C~}(1) \\
\operatorname{Csl}(2) \\
\operatorname{Css}(7) \\
\operatorname{RF}(4)\end{array}$ \\
\hline $\begin{array}{l}\text { Enterolobium } \\
\text { contortisiliquum } \\
\text { (Vell.) Morong }\end{array}$ & $\begin{array}{l}\text { Timburi, timbaúva, } \\
\text { tamboril, pacará, } \\
\text { orelha-de-macaco, } \\
\text { orelha-de-negro }\end{array}$ & Fabaceae & tree & $\begin{array}{l}\mathrm{CSl} \\
\mathrm{RF}\end{array}$ & $\begin{array}{l}C(2) \\
\operatorname{CsS}(3) \\
\operatorname{MS}(2) \\
\operatorname{RF}(7) \\
\mathbf{V}(\mathbf{1})\end{array}$ \\
\hline $\begin{array}{c}\text { Eugenia dysenterica } \\
\text { (Mart.) DC. }\end{array}$ & Cagaiteira, cagaita & Myrtaceae & $\begin{array}{l}\text { shrub or } \\
\text { tree }\end{array}$ & $\begin{array}{l}\text { C } \\
\text { Csl } \\
\text { Css } \\
\text { RF }\end{array}$ & $\begin{array}{l}\text { CSI (2) } \\
\text { CSS (7) } \\
\text { MS (1) } \\
\text { QRG (1) } \\
\text { RF (1) }\end{array}$ \\
\hline
\end{tabular}


Table VII. Continuation.

\begin{tabular}{|c|c|c|c|c|c|}
\hline Genipa Americana L. & $\begin{array}{c}\text { Jenipapeiro, } \\
\text { jenipapo, jenipapo, } \\
\text { janipapeiro }\end{array}$ & Rubiaceae & $\begin{array}{l}\text { shrub or } \\
\text { tree }\end{array}$ & $\begin{array}{l}\mathrm{C} \\
\mathrm{Csl} \\
\mathrm{RF}\end{array}$ & $\begin{array}{c}\text { C (2) } \\
\text { Css (3) } \\
\operatorname{RF}(5) \\
\text { V (1) }\end{array}$ \\
\hline $\begin{array}{c}\text { Guazuma ulmifolia } \\
\text { Lam. }\end{array}$ & $\begin{array}{c}\text { Mutamba, } \\
\text { mutambo, } \\
\text { mucungo, pau-de- } \\
\text { pomba, embieira }\end{array}$ & Malvaceae & tree & $\begin{array}{c}\text { C } \\
\text { Csl } \\
\text { MS } \\
\text { RF }\end{array}$ & $\begin{array}{c}\text { CSS (3) } \\
\text { MS (1) } \\
\text { RF (5) } \\
V(1)\end{array}$ \\
\hline $\begin{array}{c}\text { Hymenaea courbaril } \\
\text { L. }\end{array}$ & $\begin{array}{c}\text { Jatobá, jatobá- } \\
\text { da-mata, jataí, } \\
\text { jataí-peba, jataíba, } \\
\text { burandã }\end{array}$ & Fabaceae & tree & $\begin{array}{l}\mathrm{C} \\
\mathrm{Csl} \\
\mathrm{RF}\end{array}$ & $\begin{array}{c}\text { C (2) } \\
\text { CSS (4) } \\
\text { MS (1) } \\
\operatorname{RF~(4)~} \\
\text { V (1) }\end{array}$ \\
\hline $\begin{array}{l}\text { Myracrodruon } \\
\text { urundeuva Allemão. }\end{array}$ & $\begin{array}{l}\text { Aroeira, aroeira- } \\
\text { do-sertão, } \\
\text { urundeúva, } \\
\text { uriunduba }\end{array}$ & Anacardiaceae & tree & $\begin{array}{c}C \\
\text { CSS } \\
\text { MS } \\
\text { RF }\end{array}$ & $\begin{array}{l}\text { CSS (3) } \\
\text { MS (2) } \\
\text { RF (5) }\end{array}$ \\
\hline $\begin{array}{c}\text { Peltophorum } \\
\text { dubium (Spreng.) } \\
\text { Taub. }\end{array}$ & $\begin{array}{c}\text { Canafistula, } \\
\text { cambuí, ibirá-puitá, } \\
\text { tamboril-bravo }\end{array}$ & Fabaceae & tree & $\begin{array}{l}\text { Csl } \\
\text { MS } \\
\text { RF }\end{array}$ & $\begin{array}{l}\text { C (2) } \\
\text { Csl (1) } \\
\operatorname{Css}(3) \\
\operatorname{RF}(4)\end{array}$ \\
\hline $\begin{array}{l}\text { Schinus } \\
\text { terebinthifolius } \\
\text { Raddi }\end{array}$ & $\begin{array}{c}\text { Aroeira-vermelha, } \\
\text { aroeira-pimenteira, } \\
\text { poivre-rose }\end{array}$ & Anacardiaceae & $\begin{array}{l}\text { shrub or } \\
\text { tree }\end{array}$ & $\begin{array}{l}\mathrm{CL} \\
\mathrm{Csl} \\
\mathrm{CSS} \\
\mathrm{RF}\end{array}$ & $\begin{array}{c}\text { C (2) } \\
\operatorname{Css}(4) \\
\operatorname{RF}(4) \\
V(1)\end{array}$ \\
\hline $\begin{array}{l}\text { Tapirira guianensis } \\
\text { Aubl. }\end{array}$ & $\begin{array}{l}\text { Peito-de-pombo, } \\
\text { pau-pombo, } \\
\text { camboatá }\end{array}$ & Anacardiaceae & tree & $\begin{array}{c}C \\
\text { CSl } \\
\text { CSS } \\
\text { MS } \\
\text { RF }\end{array}$ & $\begin{array}{c}\text { Csl (1) } \\
\text { Css (5) } \\
\operatorname{RF}(3) \\
\text { V (1) }\end{array}$ \\
\hline
\end{tabular}

presence of exotic invasive species is often a challenge in restoration sites, requiring the use of some control technique (Assis et al. 2020). The landscape approach should be considered when designing cost-effective restoration strategies for the Cerrado, especially regarding the dominance of agribusiness in its current landscape and the importance of integrating restoration sites together and with native areas (Metzger et al. 2017, Molin et al. 2018, Rajão et al.
2020). Nonetheless, such procedures should be carefully done as they need consider the high level of degradation as an indicator for high restoration necessity even though it may request high costs. Hence, ecological restoration goals should include ecological and socioeconomic aspects to provide important feedbacks to assist the achievement of ecological restoration goals (Kong et al 2018, Lin et al. 2012). 
Another challenge that must be faced is the shift from a non-standardized form of assessing restoration outcomes to a systematic form. The importance of periodically measuring ecosystem indicators to assist decision-making about the requirement of management activities and/or to assist future restoration initiatives is well known (Le et al. 2012, McDonald et al. 2016). However, we found that monitoring of Cerrado restoration research has not be done in a systematic way. The absence of a clear policy towards periodical evaluation of restoration outcomes is a challenge to be faced (Nunes et al. 2016). The absence of regular and consistent monitoring may be related to short-term investments (Le et al. 2012) by companies and/or insufficient community involvement (Pareja et al. 2018). Short-term monitoring is important for assessing initial outcomes, however, evaluation of restoration progress must also include long-term monitoring (Kollmann et al. 2016, Nunes et al. 2016). Longterm monitoring allows decision-makers to better understand restoration trajectories as it shows how restoration results can change over time (Gomes et al. 2018). Besides, it can predict important adaptative management strategies to provide ecosystem services (Nunes et al. 2016). Determining appropriate monitoring measures is crucial, as is adequate periodicity and feasibility of low-cost standardized methods (Kollmann et al. 2016, Nunes et al. 2016). Hence, we highlight the importance of establishing a policy that comprises basic requirements for restoration research. Requirements related to monitoring should be addressed combining short- and long-term monitoring of biophysical outcomes alongside with monitoring of socio-economic outcomes in order to evaluate success and failures of restoration and management efforts (Bustamente et al. 2019, Kollmann et al. 2016, Le et al. 2012).

\section{Plant species used in ecological restoration of Cerrado vegetation types}

Native plant species have been used in Cerrado ecological restoration with no regard to the reference ecosystem. We found that characteristics of the reference ecosystem, such as the proportion of plant growth forms and the use of native plants, have not been respected. The most used plant species have been used in the restoration of areas outside their original distribution. Furthermore, a predominance of using tree species was found, which indicates that Cerrado restoration has been influenced by practices commonly used for forest restoration. Even though the Cerrado encompasses forest vegetation types, most of this phytogeographic domain is formed of savanna and grassland vegetation types. Forests and savannas have distinct capacities for resilience and resistance, and thus demand appropriate restoration interventions that respect the functioning of each ecosystem (see Table I in the Introduction). Furthermore, even forest ecosystems have other growth forms apart from trees and their inclusion in restoration efforts has to be encouraged (Guerra et al. 2020). Therefore, Cerrado restoration should stick to the target vegetation type and use native plant species and a proper proportion of growth forms.

The main use of tree species in restoration of non-forest Cerrado vegetation types urgently needs to be changed. Most tropical old-growth savannas (dominant Cerrado vegetation type) have evolved to tolerate disturbances that remove aboveground biomass (Buisson et al. 2018). Therefore, encroachment promoted by the over usage of trees clearly impacts restored ecosystem functioning. Moreover, tree dominance can hamper spontaneous regeneration of native herbaceous grassland species (Buisson et al. 2018) and impair the restoration of old-growth savannas (Veldman et 
al. 2015a). Futhermore, failures to re-establish and maintain a grass layer can impact nonforest ecosystem functioning and diversity. For instance, restored sites of cerrado sensu strico that focused on returning tree cover have faild to re-establish compositional and functional diversity of ant communities (Laste et al. 2018). Hence, we emphasize increased usage of herbaceous plant species and respect of the proportion of plant growth forms in each vegetation type.

Many Cerrado restoration initiatives have been actually practicing afforestation instead of restoration, even if they state an intention to reestablish the native ecosystem (Fernandes et al. 2016a,c). One clear example of afforestation is the establishment of pine and eucalypts monocultures in degradaded grassland areas (e.g. Modna et al. 2010, Zinn et al. 2002). Afforestation is different from reforestation basically because in the former trees are planted in an area that has never been a forest while in the latter a forest previously existed in the degraded area (see Veldman et al. 2015a,b). The practice of afforestation in the Cerrado biome must be carefully analyzed and avoided. This inadequate practice can cause serious negative impacts at local and regional scales (Fernandes et al. 2016a), and has already threatened the functioning and biodiversity of Cerrado ecosystems.

Another problem that we acknowledge is the use of exotic species in Cerrado restoration, which has been misleadingly related to low availability of native seedlings (Da Silva et al. 2016). Although not yet widely used, the number of studies on the propagation of native Cerrado species is increasing exponentially and solutions have been proposed (e.g., Fernandes et al. 2016c,
Gomes et al. 2015, 2018). We found that species from other Brazilian biomes or even from other countries have been used in the restoration of Cerrado vegetation types (Table VIII), although less so than native species. Additionally, we found that some of the most used plant species were non-native to some Cerrado vegetation types. Some of these species were trees used to restore forest ecosystems in which they did not originally occur.

The use of exotic species in the biome, as well as in any of its specific vegetation types, can lead to the loss of genetic and functional diversity and to negative impacts on biotic interactions such as unexpected competition with native species (Nunes et al. 2016). Exotic species can become invasive and impose threats to the development of native species as they can spread throughout the landscape and change ecosystem structure and functioning (D’Antonio \& Meyerson 2002, Gorgone-Barbosa et al. 2015, Hilário et al. 2011). For instance, exotic invasive grasses are highly flamable and can increase fire frequency and/or intensity in the Cerrado, ultimately impacting the survival of native species (Gorgone-Barbosa et al. 2015). Changes in fire regime can have negative consequences for native plants despite their adaptations to fire (e.g., Buisson et al. 2018). Besides, controlling exotic invasive species is difficult and economically costly (Assis et al. 2020, Lindenmayer et al. 2015). Therefore, despite the possible benefits of using exotic species (D'Antonio \& Meyerson 2002, Ewel \& Putz 2004) we strongly encourage the use of native plant species for restoration initiatives. 
Table VIII. Plant species used in assisted regeneration of the Cerrado and exotic to the biome.

\begin{tabular}{|c|c|c|}
\hline Family & Species & Growth form \\
\hline Anacardiaceae & Mangifera indica L. & tree \\
\hline Annonaceae & Annona muricata $\mathrm{L}$. & tree \\
\hline \multirow{3}{*}{ Apocynaceae } & Aspidosperma polyneuron Müll. Arg. & tree \\
\hline & Forsteronia pilosa (Vell.) Müll. Arg. & climbing \\
\hline & Nerium oleander L. & tree \\
\hline Arecaceae & Attalea maripa (Aubl.) Mart. & herb \\
\hline Asteraceae & Helianthus annuus L. & herb \\
\hline \multirow{4}{*}{ Bignoniaceae } & Jacaranda micrantha Cham. & tree \\
\hline & Paratecoma peroba (Record) Kuhlm. & tree \\
\hline & Tabebuia capitata (Bureau \& K.Schum.) Sandwith & tree \\
\hline & Tecoma stans (L.) Juss. ex Kunth & shrub \\
\hline Clusiaceae & Garcinia brasiliensis Mart. & shrub-tree \\
\hline Combretaceae & Laguncularia racemosa (L.) C.F.Gaertn. & shrub-tree \\
\hline \multirow{2}{*}{ Euphorbiaceae } & Actinostemon concolor (Spreng.) Müll.Arg. & shrub-tree \\
\hline & Croton floribundus Spreng. & tree \\
\hline \multirow{18}{*}{ Fabaceae } & Albizia lebbeck (L.) Benth. & shrub-tree \\
\hline & Bauhinia forficata Link & tree \\
\hline & Bauhinia variegata $\mathrm{L}$. & tree \\
\hline & Caesalpinia leiostachya (Benth.) Ducke & tree \\
\hline & Caesalpinia peltophoroides Benth. & tree \\
\hline & Caesalpinia pulcherrima (L.) Sw. & shrub-tree \\
\hline & Cajanus cajan (L.) Huth & shrub \\
\hline & Dalbergia nigra (Vell.) Allemão ex Benth. & tree \\
\hline & Lonchocarpus muehlbergianus Hassl. & tree \\
\hline & Myrocarpus frondosus Allemão & tree \\
\hline & Ormosia stipularis Ducke & tree \\
\hline & Paubrasilia echinata (Lam.) Gagnon, H.C.Lima \& G.P.Lewis & tree \\
\hline & Poecilanthe parviflora Benth. & tree \\
\hline & Schizolobium parahyba (Vell.) Blake & tree \\
\hline & Senna siamea (Lam.) H.S.Irwin \& Barneby & tree \\
\hline & Sesbania sesban (L.) Merr. & shrub-tree \\
\hline & Swartzia oblata R.S.Cowan & tree \\
\hline & Tipuana tipu (Benth.) Kuntze & tree \\
\hline
\end{tabular}


Table VIII. Continuation.

\begin{tabular}{|c|c|c|}
\hline Lauraceae & Ocotea divaricata (Nees) Mez & tree \\
\hline Lecythidaceae & Cariniana legalis (Mart.) Kuntze & tree \\
\hline Malpighiaceae & Byrsonima ligustrifolia A.Juss. & tree \\
\hline \multirow{3}{*}{ Malvaceae } & Basiloxylon brasiliensis (All.) K.Schum. & tree \\
\hline & Cavanillesia arborea K. Schum. & tree \\
\hline & Pachira aquatica Aubl. & tree \\
\hline \multirow{2}{*}{ Melastomataceae } & Tibouchina granulosa (Desr.) Cogn. & shrub \\
\hline & Tibouchina mutabilis (Vell.) Cogn. & tree \\
\hline Meliacaeae & Melia azedarach L. & tree \\
\hline Moraceae & Artocarpus heterophyllus Lam. & tree \\
\hline Muntingiaceae & Muntingia calabura L. & tree \\
\hline \multirow{5}{*}{ Myrtaceae } & Myrciaria trunciflora O.Berg & tree \\
\hline & Psidium guajava L. & tree \\
\hline & Syzygium cumini (L.) Skeels & tree \\
\hline & Syzygium jambolanum (Lam.) DC. & tree \\
\hline & Syzygium jambos (L.) Alston & tree \\
\hline Pinaceae & Pinus elliotti L. & tree \\
\hline \multirow{4}{*}{ Poaceae } & Avena strigosa Schreb. & herb \\
\hline & Lolium multiflorum Lam. & herb \\
\hline & Pennisetum glaucum (L.) R.Br. & herb \\
\hline & Vetiveria zizanioides (L.) Nash & herb \\
\hline \multirow{2}{*}{ Rhamnaceae } & Hovenia dulcis Thunb. & tree \\
\hline & Ziziphus joazeiro Mart. & tree \\
\hline
\end{tabular}

\section{CONCLUSIONS}

The challenge of reducing rates of biodiversity loss and ecosystem degradation calls for effective conservation and ecological restoration actions, especially regarding threatened nonforest ecosystems. This review is among the first attempts to capture how research on the restoration of the Cerrado has been conducted, and has revealed that we still have a long way to go to restore the diversity of this biome. Recommendations established in the ecological restoration literature (e.g. clearly determine the reference ecosystem, use of native species, include ecosystem functions among the goals, etc; Kollmann et al. 2016, McDonald et al. 2016) must be followed in order to overcome challenges and improve ecological restoration of the Cerrado. Many of the results of Cerrado restoration efforts cannot be generalized, although the establishment of some basic requirements for research would better support decision-making as they would allow successes and failures to be measured and compared among studies. The clear establishment of the reference ecosystem and the objective of 
restoration research, as well as the appropriate monitoring periodicity, are keys to achieving this. More precise comparisons will promote a shift in restoration studies from a case-specific approach (e.g. trial and error) to a more applicable and evidence-based scientific approach. Furthermore, restoration efforts should raise concern about the plant species, particularly their growth form and their original occurrence, used to restore each Cerrado vegetation type. The main use of native plant species should increase, and native plant species cultivation should be improved (e.g. how to produce native seedlings on a large scale). Furthermore, investigations on ecological dynamics and natural regeneration of the different vegetation types of the Cerrado should be encouraged in order to build a consistent ecological knowledge base. The use of new tools and frameworks should be explored to better assist decisionmakers when planning restoration at the Cerrado biome level (Metzger et al. 2017). Finally, we highlight the importance of integrating limited budgets, community engagement and compliance with environmental laws to promote the knowledge advances mentioned above, and argue that restoration research in the Cerrado should receive more support.

\section{Future perspectives}

Although difficult, ecological restoration of the Cerrado must include all dimensions of its diversity, and not only focus on species compositional diversity. Research efforts directed towards genetic, compositional, functional and phylogenetic diversity are essential to better understand and (re)establish Cerrado biodiversity (e.g. Fernandes et al. 2020). Moreover, the relationship between diversity and invasion resistance should also be explored to provide better guidance for decision-making. Monitoring will be a key in such research and so it is important to implement it in a standardized form. Furthermore, from the functional diversity perspective, we noticed that some growth forms, such as herbs, were not commonly used in restoration even though they form an important component of Cerrado vegetation. This may be due to the difficulties involved in cultivating seedlings of native herbaceous plants (Fernandes et al. 2016c, Ribeiro et al. 2016) and highlights the need to develop research that aims to better understand and replicate the reproduction of herbaceous plants. Additionally, questions related to the impacts of large-scale restoration remain unsolved (Chazdon 2008). Finally, we advocate the construction of an open and free database encompassing information about restoration actions and outcomes because it could gather information to help future decision-making.

\section{Acknowledgments}

The authors thankfully acknowledge the support provided by colleagues from the Programa de Pesquisa em Biodiversidade (PPBio), especially Hernani Alves de Almeida e Barbara Rubia da Silveira for their contribution in data acquisition. This work was financed in part by the Coordenação de Aperfeiçoamento de Pessoal de Nivel Superior - Brasil (CAPES) - Finance Code 001 (scholarship to NFM) and by the Conselho Nacional de Desenvolvimento Científico e Tecnológico (CNPq, including grant number 305739/2019-0). We are also thankful to PROECOS, P\&D Aneel/Cemig, GT599.

\section{REFERENCES}

ALVARADO ST, FORNAZARI T, CÓSTOLA A, MORELLATO LPC \& SILVA TSF. 2017. Drivers of fire occurrence in a mountainous Brazilian cerrado savanna: tracking long-term fire regimes using remote sensing. Ecol Indic 78: 270-281.

ASSIS GB, PILON NAL, SIQUEIRA MF \& DURIGAN G. 2020. Effectiveness and costs of invasive species control using different techniques to restore cerrado grasslands. Restor Ecol: doi https://doi.org/10.1111/rec.13219.

AUDINO LD, MURPHY SJ, ZAMBALDI L, LOUZADA J \& COMITA LS. 2017. Drivers of community assembly in tropical forest 
restoration sites: role of local environment, landscape, and space. Ecol Appl 27: 1731-1745.

BARBOSA NPU, FERREIRA JA, NASCIMENTO CAR, SILVA FA, CARVALHO VA, XAVIER ERS, RAMON L, ALMEIDA AC, CARVALHO MD \& CARDOSO AV. 2018. Prediction of future risk of invasion by Limnoperna fortunei (Dunker, 1857) (Mollusca, Bivalvia, Mytilidae) in Brazil with cellular automata. Ecol Indic 92: 30-39.

BARLOW J ET AL. 2016. Anthropogenic disturbance in tropical forests can double biodiversity loss from deforestation. Nature 535: 144-159.

BOND WJ \& PARR CL. 2010. Beyond the forest edge: ecology, diversity and conservation of the grassy biomes. Biol Conserv 143: 2395-2404.

BRASIL. 2012a. Lei Federal 12.651, de 25 de maio de 2012. Dispõe sobre a proteção da vegetação nativa e dá outras providências. http://www.planalto.gov.br/ccivil_03/_ ato2011-2014/2012/lei/l12651.htm (accessed 09 August 2020).

BRASIL. 2012b. Decreto 7.830, de 17 de outubro de 2012. Instituiu o Sistema de Cadastro Ambiental Rural, estabelece normas de caráter geral aos Programas de Regularização Ambiental de que trata a Lei Federal 12.651, de 25 de maio de 2012, e dá outras providências. http:// www.planalto.gov.br/ccivil_03/_Ato2011-2014/2012/ Decreto/D7830.htm (accessed 09 August 2020).

BUISSON E ET AL. 2018. Resilience and restoration of tropical and subtropical grasslands, savannas, and grassy woodlands. Biol Rev 92: 590-609.

BUSTAMANTE MMC ET AL. 2019. Ecological restoration as a strategy for mitigating and adapting to climate change: lessons and challenges from Brazil. Mitig Adapt Strat Gl 24: $1249-1270$.

CAMPOE OC, IANNELI C, STAPE JL, COOK RL, MENDES JCT \& VIVIAN R. 2014. Atlantic forest tree species responses to silvicultural practices in a degraded pasture restoration plantation: from leaf physiology to survival and initial growth. Forest Ecol Manag 313: 233-243.

CHAZDON RL. 2008. Beyond deforestation: restoring forests and ecosystem services on degraded lands. Science 320: 1458-1460.

CHAZDON RL \& GUARIGUATA MR. 2016. Natural regeneration as a tool for large-scale forest restoration in the tropics: prospects and challenges. Biotropica 48: 716-730.

COUTO MSDS, SMITH OP \& TEIXEIRA RA. 2011. Modelagem matemática para seleção de áreas prioritárias à conservação ou restauração no Cerrado Goiano. Mercator 10: 225-236.
CROUZEILLES R, FERREIRA MS, CHAZDON RL, LINDENMAYER DB, SANSEVERO JBB, MONTEIRO L, IRIBARREM A, LATAWIEC AE \& STRASSBURG BBN. 2017. Ecological restoration success is higher for natural regeneration than for active restoration in tropical forests. Sci Adv 3: e1701345.

D'ANTONIO C \& MEYERSON LA. 2002. Exotic plant species as problems and solutions in ecological restoration: a synthesis. Restor Ecol 10: 703-713.

DA SILVA AM, CANUTO DSO, ALVES MC, BUZETTI S, MORAES MLT \& SAKAMOTO AY. 2016. Características químicas de um latossolo vermelho em recuperação sob plantio de Pinus spp. Cienc Florest 26: 1049-1060.

DE MONTJOYE YA, STOPCZYNSKI A, SHMUELI E, PENTLAND A \& LEHMANN S. 2014. The strength of the strongest ties in collaborative problem solving. Sci Rep: doi 10.1038/ srep05277.186.

DE SOUZA RA, DANTAS PVP, CAVALCANTE PF, TENÓRIO RR \& HOULLO LM. 2017. Basic procedure for the in vitro propagation of Brazilian trees for restoration purposes. J Environ Anal Progr 02: 107-114.

ENGEL VL \& PARROTTA JA. 2001. An evaluation of direct seeding for reforestation of degraded lands in central São Paulo state, Brazil. Forest Ecol Manag 152: 169-181.

EWEL JJ \& PUTZ FE. 2004. A place for alien species in ecosystem restoration. Front Ecol Environ 2: 354-360.

FAHRIG L. 2003. Effects of habitat fragmentation on biodiversity. Annu Rev Ecol Evol Syst 34: 487-515.

FERNANDES GW, COELHO MS, MACHADO RB, FERREIRA ME, AGUIAR LMS, DIRZO R, SCARIOT A \& LOPES CR. 2016a. Afforestation of savannas: an impeding ecological disaster. Nat Conservacao 14: 146-151.

FERNANDES GW ET AL. 2016b. Cerrado: em busca de soluções sustentáveis. Rio de Janeiro: Vertente, 212p.

FERNANDES GW, TOMA TSP, ANGRISANO P \& OVERBECK G. 2016c. Challenges in the restoration of quartzitic and ironstone rupestrian grasslands. In: Fernandes GW (Eds), Ecology and conservation of mountaintop grassland in Brazil: Springer International Publusing, Switzerland, p. 449-478. FERNANDES GW, BARBOSA NPU, ALBERTON B, BARBIERI A, DIRZO R, GOULART F, GUERRA TJ, MORELLATO LPC \& SOLAR RRC. 2018. The deadly route to collapse and the uncertain fate of Brazilian rupestrian grasslands. Biodivers Conserv 27: 2587-2603.

FERNANDES GW ET AL. 2020. Floristic and functional identity of rupestrian grasslands as a subsidy for environmental restoration and policy. Ecol Complex 43: 100833. 
FERREIRA MC, WALTER BMT \& VIEIRA DLM. 2015. Topsoil translocation for Brazilian savanna restoration: propagation of herbs, shrubs, and trees. Restor Ecol 23: 723-728.

FIRN J, HOUSE APN \& BUCKLEY YM. 2010. Alternative states models provide an effective framework for invasive species control and restoration of native communities. J Appl Ecol 47: 96-105.

FLORA DO BRASIL. 2020. Jardim Botânico do Rio de Janeiro. http://floradobrasil.jbrj.gov.br/ (accessed 25 March 2020).

GOMES VM, NEGREIROS D, CARVALHO V \& FERNANDES GW. 2015. Crescimento e desempenho de espécies nativas de campo rupestre em áreas degradadas quartzíticas. Neotrop Biol Conserv 10: 159-168.

GOMES VM, NEGREIROS D, FERNANDES GW, PIRES ACV, SILVA ACDR \& LE STRADIC S. 2018. Long-term monitoring of shrub species translocation in degraded Neotropical mountain grassland. Restor Ecol 26: 91-96.

GORGONE-BARBOSA E, PIVELLO VR, BAUTISTA S, ZUPO T, RISSI MN \& FIDELIS A. 2015. How can na invasive grass affect fire behavior in a tropical savanna? A community and individual plant level approach. Biol Invasions 17: 423-431.

GUERRA A ET AL. 2020. Ecological restoration in Brazilian biomes: identifying advances and gaps. Forest Ecol Manag 458: 117802.

HILÁRIO RR, CASTRO SAB, KER FTO \& FERNANDES GW. 2011. Unexpected effects of pigeon-peas (Cajanus cajan) in the restoration of rupestrian fields. Planta Daninha 29: 717-723.

KLINK CA \& MACHADO RB. 2005. A conservação do Cerrado brasileiro. Megadiversidade 1: 147-155.

KOLLMANN J ET AL. 2016. Integrating ecosystem functions into restoration ecology-recent advances and future directions. Restor Ecol 24: 722-730.

KONG L, ZHENG H, RAO E, XIAO Y, OUYANG Z \& LI C. 2018. Evaluating indirect and direct effects of eco-restoration policy on soil conservation servisse in Yangtze River Basin. Sci Total Environ 631-632: 887-894.

LASTE KCD, DURIGAN G \& ANDERSEN AN. 2018. Biodiversity responses to land-use and restoration in a global biodiversity hotspot: ant communities in Brazilian Cerrado. Austral Ecol 44: 313-326.

LAURANCE WF, SAYER J \& CASSMAN KG. 2014. Agricultural expansion and its impacts on tropical nature. Trends Ecol Evol 29: 107116.
LE HD, SMITH C, HERBOHN J \& HARRISON S. 2012. More than just trees: assessing reforestation success in tropical developing countries. J Rural Stud 28: 5-19.

LIN H, QUANQIN S \& JIYUAN L. 2012. Forest restoration to achieve both ecological and economic progress, Poyang Lake basin, China. Ecol Eng 44: 53-60.

LINDENMAYER DB, WOOD J, MACGREGOR C, BUCKLEY YM, DEXTER N, FORTESCUE M, HOBBS RJ \& CATFORD JA. 2015. A long-term experimental case study of the ecological effectiveness and cost effectiveness of invasive plant management in achieving conservation goals: Bitou bush control in Booderee National Park in eastern Australia. PLoS ONE 10: e0128482.

LORENZI H. 1992. Árvores brasileiras: manual de identificação e cultivo de plantas arbóreas nativas do Brasil, 1a ed., vol. I, II \& III. Nova Odessa: Plantarum.

LUZ GR, MOTA GS, SPADETO C, TOLENTINO GS, FERNANDES GW \& NUNES YRF. 2018. Regenerative potential of the soil seed bank along an elevation gradient of rupestrian grassland in southeastern Brazil. Botany-Botanique 96: 281-298.

MCDONALD T, GANN G, JONSON J \& DIXON K. 2016. International standards for the practice of ecological restoration including principles and key concepts, Washington: Society for Ecological Restoration.

METZGER JP ET AL. 2017. Best practice for the use of scenarios for restoration planning. Curr Opin Env Sust 29: $14-25$.

MINISTÉRIO do meIO AmBIENTE. 2017. PLANAVEG: Plano Nacional de Recuperação da Vegetação Nativa. Brasília: Ministério do Meio Ambiente, Ministério da Agricultura, Pecuária e Abastecimento, Ministério da Educação, 73 p. MODNA D, DURIGAN G \& VITAL MVC. 2010. Pinus elliotti Engelm como facilitadora da regeneração natural da mata cilia rem região de Cerrado, Assis, SP, Brasil. Sci For 38: 73-83

MOLIN PG, CHAZDON R, FERRAZ SFB \& BRANCALION PHS. 2018. A landscape approach for cost-effective large-scale forest restoration. J Appl Ecol 55: 2767-2778.

MONTOYA D, ROGERS L \& MEMMOTT J. 2012. Emerging perspectives in the restoration of biodiversity-based ecosystem services. Trends Ecol Evol 27: 666-672.

MYERS JA \& HARMS KE. 2011. Seed arrival and ecological filters interact to assemble high-diversity plant communities. Ecology 92: 676-686.

MYERS N, MITTERMEIER RA, MITTERMEIER CG, FONSECA GAB \& KENT J. 2000. Biodiversity hotspots for conservation priorities. Nature 403: 853-858. 
NEWBOLD T ET AL. 2015. Global effects of land use on local terrestrial biodiversity. Nature 520: 45-50.

NIMMO DG, NALLY RM, CUNNINGHAM SC, HASLEM A \& BENNETT AF. 2015. Vive la résistance: reviving resistance for 21st century conservation. Trends Ecol Evol 30: 516-523.

NUNES A ET AL. 2016. Ecological restoration across the Mediterranean Basin as viewed by practioners. Sci Total Environ 566: 722-732.

OLIVEIRA-FILHO AT \& RATTER JA. 2002. Vegetation physiognomies and woody flora of the Cerrado Biome. In: Oliveira PS \& Marquis RJ (Eds), The Cerrados of Brazil - Ecology and natural history of a neotropical savanna: Columbia University Press, New York, p. 91-121.

OVERBECK GE ET AL. 2015. Conservation in Brazil needs to include non-forest ecosystems. Divers Distrib 21: 1455-1460.

PAREJA C, HONEY-ROSÉS J, KUNKZ NC, FRASER J \& XAVIER A. 2018. What participation? Distinguishing water monitoring programs in mining regions based on Community participation. Water 10: 1325.

PARR CL, LEHMANN CER, BOND WJ, HOFFMANN WA \& ANDERSEN AN. 2014. Tropical grassy biomes: misunderstood, neglected, and under threat. Tends Ecol Evol 29: 205-213.

PIOTTO D, CRAVEN D, MONTAGNINI F, ASHTON M, OLIVER C \& THOMAS WW. 2019. Successional, spatial, and seasonal changes in seed rain in the Atlantic forest of southern Bahia, Brazil. PLoS ONE 14: e0226474.

PIVELLO VR. 2011. The use of fire in the Cerrado and Amazonian rainforests of Brazil: past and present. Fire Ecol 7: 24-39.

R CORE TEAM. 2017. R: a language and environment for statistical computing. R Foundation for Statistical Computing https://www.R-project.org/ (accessed 25 March 2020).

RAJÃO R ET AL. 2020. The rotten apples of Brazil's agribusiness. Science 369: 246-248.

RANDS MRW et al. 2010. Biodiversity conservation: challenges beyond 2010. Science 329: 1298-1303.

RIBEIRO JF \& WALTER BMT. 1998. Fitofisionomias do bioma Cerrado. In: Sano SM \& Almeida SP (Eds), Cerrado: ambiente e flora: Embrapa Cerrados, Planaltina, p. 89-166.

RIBEIRO GVT, TEIXIDO AL, BARBOSA NPU \& SILVEIRA FAO. 2016. Assessing bias and knowledge gaps on seed ecology research: implications for conservation agenda and policy. Ecol Appl 26: 2033-2043.

RICHARDSON BJ \& LEFROY T. 2016. Restoration dialogues: improving the governance of ecological restoration. Restor Ecol 24: 668-673.
RODRIGUES RR, LIMA RAF, GANDOLFI S \& NAVE AG. 2009. On the restoration of high diversity forests: 30 years of experience in the Brazilian Atlantic Forest. Biol Conserv 142: 1242-1251.

SALAZAR A, GOLDSTEIN G, FRANCO AC \& MIRALLES-WILHELM F. 2011. Timing of seed dispersal and dormancy, rather than persistent soil seed-banks, control seedling recruitment of woody plants in Neotropical savannas. Seed Sci Res 21: 103-116.

SANO SM, ALMEIDA SP \& RIBEIRO JF. 2008. Cerrado: ecologia e flora, vol. 01. Planaltina: Embrapa, 406 p.

SANTILLI C \& DURIGAN G. 2014. Do alien species dominate plant communities undergoing restoration? A case study in the Brazilian savanna. Sci For 42: 371-382.

SCARAMUZZA ET AL. 2017. Land-use and land-cover mapping of the brazilian Cerrado based mainly on landsat-8 satellite images. Rev Bras Cart 69: 1041-1051.

SCHMIDT IB, FERREIRA MC, SAMPAIO AB, WALTER BMT, VIEIRA DLM \& HOLL KD. 2019. Tailoring restoration interventions to the grassland-savanna-forest complex in central Brazil. Restor Ecol 27: 942-948.

SILVA RRP, OLIVEIRA DR, ROCHA GPE \& VIEIRA DLM. 2015. Direct seeding of Brazilian savanna trees: effects of plant cover and fertilization on seedling establishment and growth. Restor Ecol 23: 393-401.

SILVA RO, BARIONI LG, HALL JAJ, MORETTI AC, VELOSO RF, ALEXANDER P, CRESPOLINI M \& MORAN D. 2017. Sustainable intensification of Brazilian livestock production through optimized pasture restoration. Agr Syst 153: 201-211.

SILVEIRA FAO ET AL. 2016. Ecology and evolution of plant diversity in the endangered campo rupestre: a neglected conservation priority. Plant Soil 403: 129-152.

SIMÕES LB, RIBEIRO FL, DAINESE RC, CARDOSO LG \& CAMPOS S. 2002 Priority areas for riparian forest restoration in Southeastern Brazil. Sci For 61: 113-121.

SKOGLUND J. 1992. The role of seed banks in vegetation dynamics and restoration of dry tropical ecosystems. J Veg Sci 3: 357-360.

SPAROVEK G, BERNDS G, BARRETO AGOP \& KLUG ILF. 2012. The revision of the Brazilian Forest Act: increased deforestation or a historic step towards balancing agricultural development and nature conservation? Environ Sci Policy 16: 65-72.

STRASSBURG BBN ET AL. 2017. Moment of truth for the Cerrado hotspot. Nat Ecol Evol: doi 10.1038/ s41559-017-0099.

SUDING KN. 2011. Toward an era of restoration in ecology: successes, failures, and opportunities ahead. Annu Rev Ecol Environ Syst 42: 465-487.

SUDING K ET AL. 2015. Committing to ecological restoration. Science 348: 638-640. 
VELDMAN JW, OVERBECK GE, NEGREIROS D, MAHY G, LE STRADIC S, FERNANDES GW, DURIGAN G, BUISSON E, PUTZ FE \& BOND WJ. 2015a. Where tree planting and forest expansion are bad for biodiversity and ecosystem services. Bioscience 65 : 1011-1018.

VELDMAN JW ET AL. 2015b. Toward an old-growth concept for grasslands, savanas, and woodlands. Front Ecol Environ 13: 154-162.

VENTER ZS, HAWKINS H \& CRAMER MD. 2017. Implications of historical interactions between herbivory and fire for rangeland management in African savannas. Ecosphere 8: 1-14.

VESK PA \& WESTOBY M. 2004. Sprouting ability across diverse disturbances and vegetation types worldwide. J Ecol 92: 310-320.

VIEIRA RRS, RIBEIRO BR, RESENDE FM, BRUM FT, MACHADO N, SALES LP, MACEDO L, SOARES-FILHO B \& LOYOLA R. 2017. Compliance to Brazil's Forest Code will not protect biodiversity and ecosystem services. Divers Distrib 24 : 434-438.

ZINN YL, RESCK DVS \& DA SILVA JE. 2002. Soil organic carbon as affected by afforestation with Eucalyptus and Pinus in the Cerrado region of Brazil. Forest Ecol Manag 166: 285-294.

\section{SUPPLEMENTARY MATERIAL}

Table SI. The 145 publications selected to assess the Cerrado restoration panorama.

Table SII. Steps of the selection of the plant species considered for the evaluation of how plant species have been used for ecological restoration in the Cerrado. When there was a thesis or dissertation that has been published as an article and the same plant species occurred in both publications, they were considered only one time.

\section{How to cite}

MEDEIROS NF, FERNANDES GW, RABELLO AM, BAHIA TO \& SOLAR RRC. 2021. Can our current knowledge and practice allow ecological restoration in the Cerrado?. An Acad Bras Cienc 94: e20200665. DOI 10.1590/0001-3765202120200665.

Manuscript received on April 30, 2020;

accepted for publication on February 13, 2021

\section{NATÁLIA F. MEDEIROS ${ }^{1}$}

https://orcid.org/0000-0002-2534-9191

GERALDO WILSON FERNANDES ${ }^{2}$

https://orcid.org/0000-0003-1559-6049

\section{ANANZA MARA RABELLO 3}

https://orcid.org/0000-0003-4089-251X

THAÍSE O. BAHIA ${ }^{4}$

https://orcid.org/0000-0003-3556-6867

\section{RICARDO R.C. SOLAR ${ }^{2}$}

https://orcid.org/0000-0001-5627-4017

${ }^{1}$ Universidade Federal de Minas Gerais, Programa de Pósgraduação em Ecologia, Conservação e Manejo da Vida Silvestre, Instituto de Ciências Biológicas, Avenida Antônio Carlos, 6627, 31270-901 Belo Horizonte, MG, Brazil

${ }^{2}$ Universidade Federal de Minas Gerais, Departamento de Genética, Ecologia e Evolução, Instituto de Ciências Biológicas, Avenida Antônio Carlos, 6627, 31270-901 Belo Horizonte, MG, Brazil ${ }^{3}$ Universidade Federal do Sul e Sudeste do Pará, Instituto de Estudos do Xingu, Loteamento Cidade Nova, Lote n1, QD15, Setor 15, Avenida Norte Sul, 68380-000 São Félix do Xingu, PA, Brazil

${ }^{4}$ Universidade Federal de Ouro Preto, Programa de PósGraduação em Ecologia de Biomas Tropicais, Departamento de Biodiversidade, Evolução e Meio Ambiente (DEBIO), Rua Professor Geraldo Nunes, s/n, 35400-000 Ouro Preto, MG, Brazil

Correspondence to: Ricardo Ribeiro de Castro Solar E-mail:rrsolar@gmail.com

\section{Author contributions}

NFM, RRCS, GWF conceived and designed the research; NFM, $A M R$, TOB, performed the searches and screening the articles in the selected databases; NFM, RRCS analyzed the data; NFM and RRCS wrote the first draft of the manuscript and all authors contributed to the final version of the manuscript

\section{(cc) BY}

